\title{
Comparing non-operative management and surgical fixation in treatment of clavicle fractures
}

Mohammad Abdallah Yahya Alhakamy ${ }^{(1)}$, Ahmad Sameer Ahmad Alrefaie ${ }^{(1)}$, Alhassan, Mahdi Ali Kariri ${ }^{(1)}$, Ali Mahdi Ali Kariri ${ }^{(1)}$, Nedaa Sameer Abdo Jelan ${ }^{(1)}$, Mohammed Bahkali Ali Altherwi $^{(1)}$, Alaa Ahmad Hassan Allayl ${ }^{(1)}$, Asim Bishi Mohammed Hakami ${ }^{(1)}$, Hiba Salah Abdelgadir ${ }^{(2)}$

(1)Faculty of Medicine, Jazan University, Saudi Arabia, (2) Family Medicine, Public and Tropical Health Program, University of Medical Sciences and Technology, Khartoum, Sudan

Corresponding author: Mohammad Abdallah Yahya Alhakamy, dr.research222@gmail.com

\begin{abstract}
:
Background: Clavicle fractures are common among males from sport injuries and the non-operative treatment has been indicated as treatment of choice. Recently, delayed healing, pain and shoulder weakness have reported as frequent complications of non-operative treatment and many studies found better outcomes with surgical treatment. This review aimed at evaluating evidence that compared nonoperative treatment and surgical intervention in management of clavicle fractures to provide evidencebased data about the best modality of treatment aiming to improve patients' outcome. Methods: A web-based search was achieved in MEDLINE resulted in 40 eligible studies. The reference lists of the articles and reviews were screened for relevant articles. After exclusion of irrelevant, duplicated and review studies, 7 studies were included in this review. Results: The outcome and success after surgical intervention compared to non-operative treatments was reported in all of the included studies. Most of the interventional studies found significant improvement in the surgical in treatment, while the majority of the non-operative group showed no improvement. Conclusions: The review of the evidence suggested that use of surgical fixation in treatment of clavicular fracture is superior to the non-operative treatment if there are no contraindications to the surgery.
\end{abstract}

Keywords: Clavicle, Fracture, Management, Surgical, Healing

\section{Background:}

The clavicle fractures are common fractures in the upper limb, accounting for 2.6 to $10 \%$ of all fractures and about $44.1 \%$ of the upper limb fractures $(1,2)$. Clavicle fractures are common among males from sport injuries. The most common cause of clavicle fracture in adults is falling down, while sport injuries is the most common cause in young and teenagers ${ }^{(3)}$.

Majority of the clavicular fractures occur in the mid shaft, and most of these fractures are displaced ${ }^{(4,5)}$. The mid shaft fractures is thought to occur as a result of direct trauma ${ }^{(3)}$. Habitually, non-operative treatment is a treatment of choice in mid shaft clavicle fractures ${ }^{(6,7)}$. The non-operative treatment for the clavicle fractures has good outcome ${ }^{(8)}$.

Recently it was noted that; the non-operative management of clavicular fractures result in high nonunion rates, especially in displaced fractures. Furthermore, the non-operative treatment is found to be associated with delayed healing, pain and shoulder weakness $(9,10)$. Surgical treatment in the past is indicated in presence of open fractures or fragments dislocation ${ }^{(11,12)}$. Recently, many studies found the surgical treatment for clavicle fractures has better outcomes ${ }^{(1,13,14)}$. This review aimed at evaluating all the studies that compared non-operative treatment and surgical intervention in management of clavicle fractures to provide evidence-based data about the best modality of treatment aiming to improve patients' outcome.

Methods:

A web-based search was achieved in MEDLINE using the following search strategy "clavicle fracture" AND ("threaded Kirschner wire " OR open fixation OR fixation) AND (non-operative $\mathrm{OR}$ nonoperative $\mathrm{OR}$ nonsurgical OR nonsurgical) AND (failure OR breakage OR success OR cure OR healing OR union OR complications OR osteomyelitis) which resulted in 40 studies. The reference lists of the articles and reviews were screened for relevant articles. After exclusion of irrelevant, duplicated and review studies, 7 studies were included in the review as they met the inclusion criteria, Figure (1). Included studies aimed at comparing the surgical treatment of clavicle fracture with the nonoperative management. 
Table (1): The findings of the included studies regarding management of clavicle fracture

\begin{tabular}{|c|c|c|c|c|c|c|c|c|c|c|c|}
\hline $\begin{array}{l}\text { Reference } \\
\text { (author } \\
\text { year) by } \\
\text { EndNote }\end{array}$ & $\begin{array}{l}\text { Study } \\
\text { design }\end{array}$ & $\begin{array}{c}\text { Sa } \\
\text { mpl } \\
\text { e } \\
\text { size }\end{array}$ & $\begin{array}{l}\text { Age of } \\
\text { patient }\end{array}$ & $\begin{array}{c}\text { Type } \\
\text { and } \\
\text { location } \\
\text { of } \\
\text { fracture }\end{array}$ & $\begin{array}{l}\text { Classificati } \\
\text { on of the } \\
\text { fracture }\end{array}$ & $\begin{array}{l}\text { Mechanis } \\
\text { m of } \\
\text { trauma } \\
\text { lead to } \\
\text { clavicle } \\
\text { fracture }\end{array}$ & $\begin{array}{c}\text { Surgical } \\
\text { intervention }\end{array}$ & 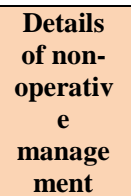 & $\begin{array}{l}\text { Follow } \\
\text {-up } \\
\text { period }\end{array}$ & $\begin{array}{c}\text { Success after } \\
\text { surgical } \\
\text { intervention }\end{array}$ & $\begin{array}{c}\text { Success } \\
\text { of non- } \\
\text { operativ } \\
\text { e }\end{array}$ \\
\hline $\begin{array}{l}\text { Coppa et } \\
\text { al. }{ }^{(I)}\end{array}$ & $\begin{array}{l}\text { Retrospe } \\
\text { ctive } \\
\text { cohort } \\
\text { study }\end{array}$ & 58 & $\begin{array}{l}\text { Mean } \\
\text { age } \\
38.35 \\
\text { years }\end{array}$ & $\begin{array}{l}\text { Mid shaft } \\
\text { clavicle } \\
\text { fracture }\end{array}$ & $\begin{array}{c}\text { Allman's } \\
\text { radiographi } \\
\text { c } \\
\text { classificatio } \\
\text { n system } \\
(1 \mathrm{~b} \& 1 \mathrm{c})\end{array}$ & $\begin{array}{l}\text { Not } \\
\text { reported }\end{array}$ & $\begin{array}{l}\text { Kirschner } \\
\text { wire }\end{array}$ & $\begin{array}{l}\text { Figure- } \\
\text { of-eight } \\
\text { bandage }\end{array}$ & $\begin{array}{l}\text { mean } \\
\text { follow- } \\
\text { up } \\
\text { of } 48 \\
\text { months }\end{array}$ & $\begin{array}{c}\text { Reduction in } \\
\text { Displacement } \\
\text { in } 25 \\
(89.29 \%) \\
\& \text { only } 3 \\
(10.71 \%) \\
\text { cases not } \\
\text { improved } \\
(\mathrm{p}=0.032)\end{array}$ & $\begin{array}{c}6 \text { cases } \\
(20.69 \% \\
) \\
\text { improve } \\
d \text {, } \\
23 \text { cases } \\
(76.67 \% \\
) \text { not } \\
\text { improve } \\
d \\
(p= \\
0.464)\end{array}$ \\
\hline $\begin{array}{l}\text { Naveen et } \\
\text { al, }^{(14)}\end{array}$ & $\begin{array}{l}\text { Prospect } \\
\text { ive non- } \\
\text { randomi } \\
\text { zed } \\
\text { compara } \\
\text { tive trial }\end{array}$ & 60 & $\begin{array}{c}20-50 \\
\text { years }\end{array}$ & $\begin{array}{c}\text { Complete } \\
\text { ly } \\
\text { displaced } \\
\text { mid-shaft } \\
\text { clavicle } \\
\text { fracture }\end{array}$ & $\begin{array}{c}\text { Allman's } \\
\text { radiographi } \\
\text { c } \\
\text { classificatio } \\
\text { n system } \\
\text { (Robinson } \\
\text { type 2b) }\end{array}$ & $\begin{array}{l}\text { RTA, fall, } \\
\text { Sports } \\
\text { injury }\end{array}$ & Plate fixation & $\begin{array}{l}\text { Figure- } \\
\text { of-eight } \\
\text { bandage } \\
\text { and } \\
\text { a sling }\end{array}$ & $\begin{array}{l}6 \\
\text { months }\end{array}$ & $\begin{array}{c}100 \% \\
\text { (all patients } \\
\text { had } \\
\text { fracture } \\
\text { union) }\end{array}$ & $93 \%$ \\
\hline $\begin{array}{c}\text { van der } \\
\text { Ven } \\
\text { Denise et } \\
\text { al. }^{(13)}\end{array}$ & $\begin{array}{l}\text { Prospect } \\
\text { ive } \\
\text { cohort } \\
\text { trial }\end{array}$ & 97 & $\begin{array}{c}16-70 \\
\text { years } \\
\\
\text { Mean } \\
\text { age } \\
40.6 \\
+/- \\
14.3\end{array}$ & $\begin{array}{l}\text { Displace } \\
\text { d mid } \\
\text { shaft } \\
\text { clavicle }\end{array}$ & $\begin{array}{l}\text { Not } \\
\text { reported }\end{array}$ & $\begin{array}{l}\text { RTA, fall, } \\
\text { sport, } \\
\text { Bicycling } \\
\text { \& skiing }\end{array}$ & $\begin{array}{l}\text { Applying the } \\
\text { VA-LCP } \\
\text { anterior } \\
\text { locking } \\
\text { compression } \\
\text { plate, and } \\
\text { sling post } \\
\text { operatively }\end{array}$ & $\begin{array}{l}\text { Use of } \\
\text { standard } \\
\text { sling for } \\
\text { two } \\
\text { weeks }\end{array}$ & 5 years & $\begin{array}{c}\text { DASH and } \\
\text { Constant } \\
\text { Scores at six } \\
\text { weeks were } \\
\text { significant } \\
\text { better } \\
(90.9+/-14.2 \\
\text { and } 15.7+/- \\
17.2)\end{array}$ & $\begin{array}{c}\text { DASH } \\
\text { and } \\
\text { Constant } \\
\text { Scores at } \\
\text { six } \\
\text { weeks } \\
(78.7 \\
17.0 \text { and } \\
24.8 \\
16.7)\end{array}$ \\
\hline $\begin{array}{c}\text { Khorami et } \\
\text { al. }^{(15)}\end{array}$ & $\begin{array}{l}\text { Prospect } \\
\text { ive non- } \\
\text { randomi } \\
\text { zed } \\
\text { clinical } \\
\text { trial }\end{array}$ & 65 & $\begin{array}{l}18-60 \\
\text { years }\end{array}$ & $\begin{array}{l}\text { Displace } \\
\text { d clavicle } \\
\text { mid-shaft } \\
\text { fractures }\end{array}$ & $\begin{array}{l}\text { Not } \\
\text { reported }\end{array}$ & $\begin{array}{l}\text { Traffic } \\
\text { accidents, } \\
\text { direct } \\
\text { trauma, } \\
\text { falling } \\
\text { down. }\end{array}$ & $\begin{array}{l}\text { Plate fixation } \\
\text { (3-5 mm DCP } \\
\text { plate with at } \\
\text { least six } \\
\text { cortical } \\
\text { screws) }\end{array}$ & $\begin{array}{l}\text { figure-of- } \\
\text { eight } \\
\text { bandage }\end{array}$ & $\begin{array}{c}6 \\
\text { months }\end{array}$ & $\begin{array}{c}\text { Average } \\
\text { durations of } \\
\text { union } 19.3 \\
\text { weeks. with } \\
\text { non-union } \\
\text { rate }=5.7 \%\end{array}$ & $\begin{array}{c}\text { Average } \\
\text { duration } \\
\text { s of } \\
\text { union } \\
24.4 \\
\text { weeks } \\
\text { with } \\
\text { non- } \\
\text { union } \\
\text { rate= } \\
13.3 \%\end{array}$ \\
\hline $\begin{array}{c}\text { Vander } \\
\text { Have et al. } \\
\text { (16) }\end{array}$ & $\begin{array}{c}\text { Retrospe } \\
\text { ctive } \\
\text { observat } \\
\text { ional } \\
\text { study }\end{array}$ & 42 & $\begin{array}{l}\text { Mean } \\
\text { age } \\
15.4 \\
(12- \\
18)\end{array}$ & $\begin{array}{l}\text { Midshaft } \\
\text { Clavicle } \\
\text { Fractures }\end{array}$ & $\begin{array}{l}\text { Not } \\
\text { reported }\end{array}$ & $\begin{array}{l}\text { Skateboard, } \\
\text { Wrestling, } \\
\text { Football, } \\
\text { Bicycle, } \\
\text { Fell off } \\
\text { bike, motor } \\
\text { vehicle } \\
\text { accident, } \\
\text { Hockey, } \\
\text { Soccer. }\end{array}$ & Plate fixation & $\begin{array}{c}\text { Sling or } \\
\text { figure-of- } \\
8 \\
\text { brace }\end{array}$ & $\begin{array}{l}\text { Not } \\
\text { reporte } \\
\text { d }\end{array}$ & $\begin{array}{l}\text { Mean time to } \\
\text { radiographic } \\
\text { union } 7.4 \\
\text { weeks }\end{array}$ & $\begin{array}{l}\text { Mean } \\
\text { time to } \\
\text { radiogra } \\
\text { phic } \\
\text { union } \\
8.7 \\
\text { weeks }\end{array}$ \\
\hline$\underset{(18)}{J u d d ~ e t ~ a l . ~}$ & $\begin{array}{l}\text { Prospect } \\
\text { ive, } \\
\text { randomi } \\
\text { zed } \\
\text { study }\end{array}$ & 57 & $\begin{array}{c}17-40 \\
\text { years }\end{array}$ & $\begin{array}{l}\text { Mid shaft } \\
\text { clavicle } \\
\text { fractures }\end{array}$ & $\begin{array}{c}\text { Single } \\
\text { Assessment } \\
\text { Numeric } \\
\text { Evaluation } \\
\text { (SANE)17 } \\
\text { and } \\
\text { L'Insalata1 } \\
8 \text { shoulder } \\
\text { scores }\end{array}$ & $\begin{array}{l}\text { Motorcycle } \\
\text { or motor } \\
\text { vehicle } \\
\text { accident, } \\
\text { contact- } \\
\text { sports } \\
\text { injury, } \\
\text { bicycle } \\
\text { accident, } \\
\text { fall. }\end{array}$ & $\begin{array}{c}\text { Open } \\
\text { reduction and } \\
\text { internal } \\
\text { fixation } \\
\text { (ORIF) }\end{array}$ & $\begin{array}{l}\text { Sling and } \\
\text { restricted } \\
\text { activity }\end{array}$ & 1 year & $\begin{array}{c}\text { Alignment } \\
\text { with healing } \\
\text { after 1 year } \\
86 \%\end{array}$ & $\begin{array}{l}\text { Alignme } \\
\text { nt with } \\
\text { healing } \\
\text { after } 1 \\
\text { year } \\
11 \%\end{array}$ \\
\hline $\begin{array}{l}\text { Smekal et } \\
\quad \text { al. }{ }^{(17}\end{array}$ & $\begin{array}{l}\text { Prospect } \\
\text { ive } \\
\text { randomi } \\
\text { zed } \\
\text { Controll } \\
\text { ed } \\
\text { Clinical } \\
\text { Trial }\end{array}$ & 60 & $\begin{array}{c}18-65 \\
\text { years }\end{array}$ & $\begin{array}{l}\text { Mid shaft } \\
\text { Clavicle } \\
\text { Fractures }\end{array}$ & $\begin{array}{c}\text { OTA } \\
\text { classificatio } \\
\text { n system }\end{array}$ & $\begin{array}{l}\text { Fall, } \\
\text { Traffic } \\
\text { accident, } \\
\text { Bicycle } \\
\text { accident, } \\
\text { Sports } \\
\text { accident. }\end{array}$ & ESIN & $\begin{array}{l}\text { Simple } \\
\text { shoulder } \\
\text { sling }\end{array}$ & 2-year & $\begin{array}{l}100 \% \text { (union } \\
\text { was achieved } \\
\text { in all patients) }\end{array}$ & $\begin{array}{c}\text { Union in } \\
70 \% \\
, 30 \% \\
\text { nonunio } \\
n\end{array}$ \\
\hline
\end{tabular}




\section{Discussion:}

Treatment of clavicle fractures can be surgical or non-surgical. This review included all randomized and non-randomized trials that compared surgical and non-operative treatment of clavicular fractures, aiming to improve the patients' outcome by using the best modality of treatment.

Regarding the type of the surgical intervention, plate fixation was used in three of the included studies ${ }^{(14-16)}$. Coppa et al. used kirschner wire in their study ${ }^{(1)}$. Van der Ven Denise et al. applied in their study the VALCP anterior locking compression plate, and used sling after the operation ${ }^{(13)}$. Judd et al, used in their study open reduction and internal fixation ${ }^{(18)}$. In Smekal et al. study, elastic stable intramedullary nailing (ESIN) is the surgical procedure that used in treatment of the mid shaft clavicle fractures ${ }^{(17)}$.

Regarding the non-operative management figure-of-eight bandage was used in four studies ${ }^{(1,14-16)}$. Vander Have et al. used in addition to figure-of-eight, a sling to some patients ${ }^{(16)}$. The rest of three included studies

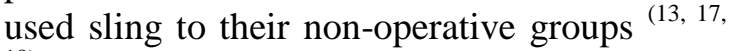
18).

Six of the included studies reported the follow up period of their included patients. Two studies followed the patients for 6 months ${ }^{(14}$, ${ }^{15)}$, one study followed the patients for one year ${ }^{(18)}$ and other one study followed the respondents for 2 years ${ }^{(17)}$. Coppa et al. reported in their study that; the mean follow up period was 48 months ${ }^{(1)}$. Van der Ven Denise et al, followed the patients for 5 years ${ }^{(13)}$.

The outcome and success after surgical intervention compared to non-operative treatments was reported in all of the included studies. In Coppa et al. study, there was significant improvement in the surgical group, while the majority of the non-operative group showed no improvement ${ }^{(1)}$. Naveen et al. reported in their study that; all patients in the surgical group showed reduction and the duration of reduction was shorter in this group (14). Van der Ven Denise et al. reported in their study that; operative fixation to clavicle fracture has positive effects in reducing the pain and early reduction when compared to non-operative treatment ${ }^{(13)}$. In Khorami et al. and Vander Have et al. studies, the non-union rates were lower in the operative group ${ }^{(15,16)}$. Vander Have et al. also reported fewer complications in the operative group ${ }^{(16)}$. Judd et al. reported in their study that; surgical intervention in clavicular fracture result in higher functional rate at short term follow up (18). In Smekal et al. study, the surgical intervention resulted in fewer nonunion cases, early reduction and return to daily activities and higher functional outcome ${ }^{(17)}$.

By reviewing the outcome of the included studies it was noted that; surgical intervention in treatment of clavicular fractures result in significant improvement ${ }^{(1)}$, early reduction ${ }^{(14,}$ ${ }^{16,18)}$, fewer non-union ${ }^{(14,15,17)}$, pain reduction (13), early return to daily activity ${ }^{(17)}$, better functional outcome (13) and fewer complications (16) when compared to nonoperative treatment. This means that if there is no contra indications surgical treatment of the clavicle fracture is the preferred treatment.

The most common types of surgical intervention in treatment of clavicular fractures is plate fixation ${ }^{(14-16)}$. Also open reduction and internal fixation ${ }^{(18)}$, kirschner wire (1) and VA-LCP anterior locking compression plate ${ }^{(16)}$ and elastic stable intramedullary nailing (ESIN) ${ }^{(17)}$ are used in treatment of clavicle fractures. Regarding the non-operative treatment of the clavicle fracture, figure-of-eight bandage is the most common used method ${ }^{(1,13-15)}$, followed by sling ${ }^{(13,16-18)}$ and restricted activity ${ }^{(18)}$.

Road traffic accidents, fall, sport injuries, bicycling and motor vehicle accidents are the most common reported causes of clavicle fractures ${ }^{(13-18)}$. Many classifications are used to diagnose clavicle fractures include: Allman's radiographic classification system ${ }^{(1}$, 14), OTA classification system (17), single assessment numeric evaluation (SANE) 17 and L'Insalata18 shoulder scores ${ }^{(18)}$.

\section{Conclusions:}

The review of the evidence suggested that the use of surgical fixation in treatment of clavicular fracture is superior to the nonoperative treatment if there are no contraindications to the surgery.

\section{References:}

1.Coppa V, Dei Giudici L, Cecconi S, Marinelli M, Gigante A (2017): Midshaft clavicle fractures treatment: threaded Kirschner wire versus conservative approach. Strategies 
Trauma Limb Reconstr., 12(3):141150.

2.Postacchini F, Gumina S, De Santis P, Albo F (2002): Epidemiology of clavicle fractures. J Shoulder Elbow Surg., 11(5):452-456.

3.Stanley D, Trowbridge E, Norris S (1988): The mechanism of clavicular fracture. A clinical and biomechanical analysis. Bone Joint J., 70(3):461-464.

4.Robinson CM (1998): Fractures of the clavicle in the adult: epidemiology and classification. J Bone Joint Surg Br., 80(3):476-484.

5.Nordqvist A, Petersson C (1994): The incidence of fractures of the clavicle. Clinical orthopaedics and related research, 300:127-132.

6.Xu J, Xu L, Xu W, Gu Y, Xu J (2014): Operative versus nonoperative treatment in the management of midshaft clavicular fractures: a metaanalysis of randomized controlled trials. J Shoulder Elbow Surg., 23(2):173-181.

7.Hubner E, Hausschild O, Sudkamp N, Strohm P (2011): Clavicle fractures - is there a standard treatment. Acta Chir Orthop Traumatol Cech., 78(4):288-296.

8.Rowe CR (1968): 4 An Atlas of Anatomy and Treatment of Midclavicular Fractures. Clin Orthop Relat Res., 58(1):29-42.

9.Hill JM, McGuire MH, Crosby LA (1997): Closed treatment of displaced middle-third fractures of the clavicle gives poor results. J Bone Joint Surg Br., 79(4):537-538.

10.Narsaria N, Singh AK, Arun G, Seth R (2014): Surgical fixation of displaced midshaft clavicle fractures: elastic intramedullary nailing versus precontoured plating. J Orthop Trauma, 15(3):165-171.

11.Van der Meijden OA, Gaskill TR, Millett PJ (2012): Treatment of clavicle fractures: current concepts review. J Shoulder Elbow Surg.,21(3):423-429.
12.Lenza M, Belloti JC, Gomes Dos Santos JB, Matsumoto MH, Faloppa F (2009): Surgical interventions for treating acute fractures or non-union of the middle third of the clavicle. Cochrane Database Syst Rev., 4:CD007428.

13.Van der Ven Denise J, Timmers $T$, Flikweert P, Van Ijseldijk A, Van Olden G (2015): Plate fixation versus conservative treatment of displaced midshaft clavicle fractures: Functional outcome and patients' satisfaction during a mean follow-up of 5 years. Injury, 46(11):2223-2229.

14. Naveen B, Joshi G, Harikrishnan B (2017): Management of mid-shaft clavicular fractures: comparison between non-operative treatment and plate fixation in 60 patients. Strategies Trauma Limb Reconstr., 12(1):11-18.

15.Khorami M, Fakour M, Mokarrami H, Arti HR, Nasab AM, Shahrivar F (2014): The comparison of results of treatment of midshaft clavicle fracture between operative treatment with plate and non-operative treatment. Arch Bone Jt Surg., 2(3):210-215.

16.Vander Have KL, Perdue AM, Caird MS, Farley FA (2010): Operative versus nonoperative treatment of midshaft clavicle fractures in adolescents. Journal of Pediatric Orthopaedics, 30(4):307-312.

17.Smekal V, Irenberger A, Struve $P$, Wambacher M, Krappinger D, Kralinger FS (2009): Elastic stable intramedullary nailing versus nonoperative treatment of displaced midshaft clavicular fractures-a randomized, controlled, clinical trial. J Pediatr Orthop Trum., 23(2):106-112.

18.Judd DB, Pallis MP, Smith E, Bottoni CR (2009): Acute operative stabilization versus nonoperative management of clavicle fractures. Am J Orthop., 38(7):341-345. 